\title{
Gastric ulcers, blood groups, and acid secretion
}

\author{
H. DAintree Johnson, A. H. G. LOVE, N. C. ROGERS, AND A. P. WyAtT
}

From London

EDITORIAL SYNOPSIS This study suggests that there are two groups of gastric ulcers, one associated with very marked blood group $\mathrm{O}$ predominance and the other with hyposecretion and no evidence of group $\mathrm{O}$ predominance and with some evidence for an excess of group $\mathrm{A}$.

When the preponderance of blood group $\mathrm{O}$ among peptic ulcer subjects was established and put on a statistically secure basis by Aird, Bentall, Mehigan, and Roberts in 1954, they remarked that it had been less among their gastric ulcer than among their duodenal ulcer subjects. However, since the difference between the sufferers from the two diseases had not been statistically significant, they did not feel justified in separating them for the purpose of comparison with the controls.

The following year one of us, describing a series of 119 cases of combined duodenal and gastric ulcers, reported that in such cases the duodenal ulcer ordinarily appears first, the patients being of the hypersecreting, duodenal-ulcer type rather than showing the minimal acid secretion found in most other gastric ulcer subjects. It was therefore suggested that gastric ulcers which occurred in the presence of gastric retention or in combination with duodenal ulcers in hypersecreting subjects were a different disease from other gastric ulcers, with incidentally a much worse prognosis (Johnson, 1955a).

It was also pointed out that these patients might be guessed to have a blood group distribution characteristic of the earlier, duodenal lesion, and that the smaller group $O$ preponderance in gastric ulcer subjects might all come from those of them who had combined lesions (Johnson, 1955b). Accordingly an investigation of the possibility was begun by collecting gastric ulcer cases and dividing them into types.

Two years later a pilot survey of 523 typed gastric ulcers was published (Johnson, 1957b) and it was reported that the combined ulcers and also the prepyloric ulcers were associated both with acid hypersecretion and, in this series, with a group $O$ excess even greater than any previously reported for duodenal ulcers. These two kinds had indeed been responsible for the whole of the overall group $O$ preponderance of the series, for the other gastric ulcers, some $60 \%$ of the total, as well as being in subjects characterized by well-marked hyposecretion, were also apparently more apt to occur in subjects with group $\mathrm{A}$ rather than group $\mathrm{O}$ blood. However, owing to the smallness of the series, the figures had only just achieved statistical significance at the conventional $5 \%$ level, and clearly called for confirmation with much larger numbers, particularly as some other small series had shown different results for antral ulcers (Billington, 1956; Balme and Jennings, 1957). More material was therefore collected over a wide area, and it is this larger series which is now being reported.

Meanwhile figures for the blood group characteristics of series from different sources of gastric ulcers composed of all types continued to be conflicting. Clarke, Cowan, Edwards, Howel-Evans, McConnell, Woodrow, and Sheppard (1955) of Liverpool, who were the first to establish the real difference between duodenal and gastric ulcer subjects, reported a significantly smaller excess of group $O$ patients among 357 with ulcers in the stomach than among 800 with duodenal ulcers. But they did not, in this series, observe any significant difference between the gastric ulcer patients and controls. On the other hand. Brown, Melrose, and Wallace (1956) reported from Scotland that among 300 gastric ulcer subjects the blood group $O$ preponderance was greater even than that among 1,642 with duodenal ulcers, though again the excess over the controls was not such that it achieved statistical significance at the $5 \%$ level.

In 1958 Billington analysed 351 combined ulcer cases extracted from previously published series to show that combined duodenal and gastric ulcer subjects did indeed have a very marked group $\mathbf{O}$ preponderance. In 1961 Grahame described the blood group characteristics of 722 duodenal and 232 gastric ulcer subjects from Tyneside. Like Daintree Johnson he found a marked group $O$ excess among those whose ulcers were prepyloric and among the combined ulcer cases. His remaining lesser curve gastric 
ulcers, which were of type I according to our classification, were also associated with a $5 \%$ excess of group A over the controls. But the series was too small for this to be significant, and it was not commented upon.

\section{MATERIAL IN THE PRESENT SERIES}

Data were collected from London, north-east England, north-west England, the west country, and Northern Ireland. Six different hospitals contributed to the London material. Since it was shown by Aird et al. (1954) that no significant differences were associated with age or sex groupings when pepticulcer/blood-group relationships were being considered, the patients were not so divided in this survey.

The gastric ulcers were originally separated into three types:

TYPE I An ulcer to the left of the gastric angulus (the lowest point of the lesser curve) without macroscopically detectable abnormality of the duodenum, pylorus, or prepyloric region.

TYPE II An ulcer to the left of the gastric angulus associated with an ulcer or scar of the duodenum or pylorus.

TYPE III A prepyloric gastric ulcer, with or without duodenal abnormality and with or without a type II ulcer proximal to it.

Later it was decided to try and keep separate those ulcers which were to the right of the gastric angulus but further than 1 in. from the pylorus (category IIIa), partly to provide a broad no-man's land between type I ulcers and truly prepyloric ulcers, and partly because we were not sure with which type ulcers in this position would best fit. Type III was to be restricted to the prepyloric inch.

However, in the event it was found that not all teams had measured the prepyloric inch with equal precision. At one large hospital measurement on radiographs had made it possible to define only $2 \%$ of ulcers as truly prepyloric, whereas in the other contributions $16-29 \%$ of ulcers had been assigned to type III. At the same time at this hospital there had also been many more other antral ulcers (category IIIa) so that the proportions of all antral ulcers together were fairly homogeneous throughout the series (Table I).

It was also found that some contributors, though they had felt able to judge an ulcer as antral by eye, had not always been able to discover from their records whether or not they had been within an inch of the pylorus and had not been able to use category IIIa at all. We have therefore decided to abandon category IIIa and put the ulcers assigned to it into type III. This probably now contains most if not all ulcers wholly to the right of the gastric angulus, though most of those at the angulus are believed to be with type I (when not of type II).

It is hardly likely that either a line at the gastric angulus or one an inch from the pylorus is the optimum frontier between ulcers of different pathogenesis and blood group characteristics. The blood group proportions among 215 patients known to have had ulcers at the angulus or between the angulus and the prepyloric inch lay between those of patients with ulcers of type I and type III, but closer to type III and with a small group $O$ preponderance over the controls. This strongly suggests that the antral ulcers nearest to the pylorus carry the highest proportion of group $\mathrm{O}$.

The difference might have been more striking if we had divided ulcers other than those of type II by their secretion habit, but unfortunately this was not practicable for so large a series drawn from a variety of places. It happens that most hyposecreting subjects develop ulcers to the left of the angulus and most hypersecreting ones with primary gastric ulcers develop them near the pylorus (Johnson, 1957b) and the anatomical classification has had to suffice.

We have observed that sometimes ulcers of the body of the stomach are associated with small, healed lesions near or on the pylorus. They would not be noticed unless carefully looked for and missing them would have led to a type II ulcer being mistaken for one of type I. (A clue is occasionally present when the patient is an acid hypersecretor or gives a history of pain at night, though it is not very often that these earlier lesions have been detected radiologically.)

Burge, Gill, and Lewis (1963) were so impressed with the discovery of some cases of this sort that they wondered whether all gastric ulcers arose in this way, a view to which our evidence lends no support. By definition patients with ulcers of type I have a normal pylorus and in our experience these are much commoner than ulcers of the body of the stomach associated with pyloric lesions.

However, because of the ease with which these scars may be overlooked we decided only to assign to type I (strict) those cases in which a careful inspection of the duodenum and pylorus had been made at operation and specifically referred to as negative in the operation notes. Other apparent type I cases were kept in a separate category Ia, mainly to be used in the totals for all types together. As might have been expected, patients with ulcers of category Ia had blood group proportions which lay 
between those of patients with strict type I ulcers and those with ulcers of type II, suggesting a contamination by about one in three of true type $I$ by unconfirmed type II cases. Some surgeons, having subscribed only patients on whom they had personally operated and in whom they had, they felt, always discovered or excluded duodenal or pyloric pathology, did not use category Ia.

If any blurring of the outlines of the three types has resulted it will have been more likely to have weakened our case than strengthened it, and this has certainly been the effect of having had to include more of the antrum in our definition of type III. It is all the more remarkable that such very clear differences have nonetheless emerged.

In all strict type I cases the diagnosis depended upon a clear surgical report. Most other patients were also surgical, but in about 100 whose ulcers were assigned to types II or III, unequivocal radiological evidence was accepted, since if any ulcer had in fact been present in addition to those obvious in the radiographs they could still not have put the patient into type $\mathrm{I}$.

\section{CONTROLS}

Consecutively registered blood donors whose addresses were within the main hinterland of each contributing hospital have been used as controls (Table IV), the figures for England having been kindly supplied by the Nuffield Blood Group Centre (Royal Anthropological Institute). All the London series have been compared with the same set of controls, those of Kopec (1963) for a western part of London in which they all lay.

\section{CHARACTERISTICS OF THE SERIES AS A WHOLE}

There were 4,201 cases of gastric ulcer in the whole series, of which 2,410 were assigned to type I $(57 \%)$, 889 were of type II ( $21 \%$ ), and 902 of type III $(21 \%)$. Of the type I ulcers 707 were put in the uncertain Ia category. The real figure for type I ulcers may therefore be very near to $50 \%$ of all surgically treated gastric ulcers; type II, 30\%; and type III, 20\%. The proportions of the three types reported from the various sources were fairly similar (Table I). The figures for cases by ulcer type and area by area are shown in Table I, the grand totals by ulcer types in Table II, and the blood group proportions with the relative incidences in Table III.

There was a typical overall blood group $O$ preponderance such that the apparent incidence of gastric ulcers of any type in persons of group $\mathbf{O}$ relative to that in persons of other groups came to $1 \cdot 19$. This is the same as the figure calculated from the combination of many areas all over the world (Fraser Roberts, 1957).

As with duodenal ulcer, the preponderance of group $\mathbf{O}$ associated with gastric ulcers of mixed types apparently varies in size from place to place by a wider margin than can reasonably be attributed to chance.

For the purposes of statistical comparison the apparent incidences of ulcers of different types in persons of different blood groups are compared by the method of Woolf (1955).

\section{TYPE I ULCER}

The 1,703 strict type I ulcer patients showed a preponderance of blood group $\mathbf{A}$ and diminution of all other groups, and so did six out of 10 individual areas (Table V). The fact that the incidence in subjects of groups $\mathrm{B}$ and $\mathrm{AB}$ as well as in those of $\mathrm{O}$ was reduced in nearly every instance suggests that type I ulcers tend to occur positively in persons of group A rather than simply not to occur in those of group $O$ but our figures for groups $B$ and $A B$ are not large enough to establish this hypothesis.

The mean weighted incidence of type $I$ ulcer in persons of group A relative to its incidence in those of other groups was $1 \cdot 14$. The excess incidence gave $\chi^{2}$ as $7 \cdot 20$ for 1 degree of freedom and was significant at a less than $1 \%$ chance of fortuity. Four of the 10 areas were also individually significant at the $5 \%$ level, and the areas with small differences in the other direction were none of them statistically significant. However, $\chi^{2}$ for heterogeneity was $22 \cdot 58$ for 9 degrees of freedom, which is too high to be attributable to chance.

TABLE IV

BLOOD GROUP DISTRIBUTION OF BLOOD DONOR CONTROLS

Blood Donor Controls

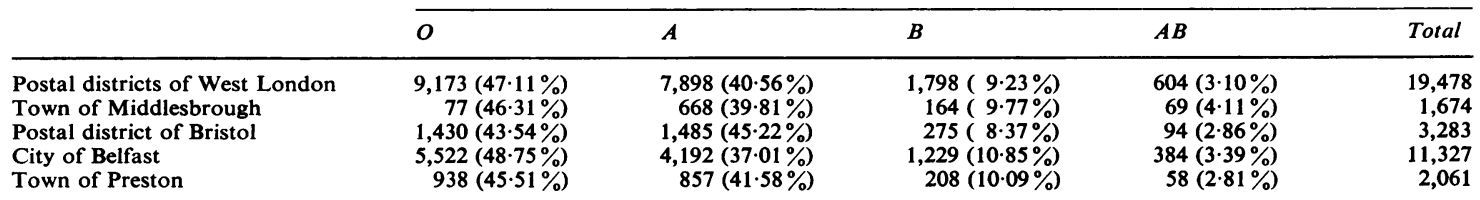


TABLE I

NUMBERS OF PATIENTS FROM EACH CENTRE WITH EACH TYPE OF ULCER HAVING BLOOD OF EACH GROUP ${ }^{1}$

\begin{tabular}{|c|c|c|c|c|c|c|}
\hline \multirow[b]{2}{*}{ Centre } & \multicolumn{6}{|c|}{ Blood Group } \\
\hline & $O$ & $A$ & $\boldsymbol{B}$ & $A B$ & Totals & $\%$ \\
\hline \multicolumn{7}{|c|}{ St. James's, Balham } \\
\hline $\begin{array}{l}\text { Type I } \\
\text { Category Ia } \\
\text { Type II } \\
\text { Type III } \\
\text { Totals }\end{array}$ & $\begin{array}{r}113 \\
17 \\
38 \\
49 \\
217\end{array}$ & $\begin{array}{r}123 \\
6 \\
45 \\
30 \\
204\end{array}$ & $\begin{array}{r}19 \\
8 \\
10 \\
37\end{array}$ & $\begin{array}{r}7 \\
1 \\
2 \\
0 \\
10\end{array}$ & $\begin{array}{r}262 \\
24 \\
93 \\
89 \\
468\end{array}$ & $\begin{array}{l}61 \\
20 \\
19\end{array}$ \\
\hline \multicolumn{7}{|c|}{ St. Bartholomews } \\
\hline $\begin{array}{l}\text { Type I } \\
\text { Category Ia } \\
\text { Type II } \\
\text { Type III } \\
\text { Totals }\end{array}$ & $\begin{array}{r}61 \\
64 \\
47 \\
26 \\
198\end{array}$ & $\begin{array}{r}85 \\
62 \\
32 \\
22 \\
201\end{array}$ & $\begin{array}{r}22 \\
10 \\
2 \\
6 \\
40\end{array}$ & $\begin{array}{r}7 \\
3 \\
3 \\
1 \\
14\end{array}$ & $\left.\begin{array}{r}175 \\
139 \\
84 \\
55 \\
453\end{array}\right\}$ & $\begin{array}{l}69 \\
18 \\
13\end{array}$ \\
\hline \multicolumn{7}{|c|}{ University College Hospital } \\
\hline $\begin{array}{l}\text { Type I } \\
\text { Category Ia } \\
\text { Type II } \\
\text { Type III } \\
\text { Totals }\end{array}$ & $\begin{array}{r}28 \\
12 \\
7 \\
31 \\
78\end{array}$ & $\begin{array}{r}19 \\
16 \\
4 \\
8 \\
47\end{array}$ & $\begin{array}{l}2 \\
1 \\
2 \\
1 \\
6\end{array}$ & $\begin{array}{l}- \\
- \\
-\end{array}$ & $\left.\begin{array}{r}49 \\
29 \\
13 \\
40 \\
131\end{array}\right\}$ & $\begin{array}{l}60 \\
10 \\
30\end{array}$ \\
\hline \multicolumn{7}{|c|}{ Central Middlesex Hospital } \\
\hline $\begin{array}{l}\text { Type I } \\
\text { Category Ia } \\
\text { Type II } \\
\text { Type III } \\
\text { Totals }\end{array}$ & $\begin{array}{r}175 \\
99 \\
52 \\
82 \\
408\end{array}$ & $\begin{array}{r}126 \\
83 \\
42 \\
81 \\
332\end{array}$ & $\begin{array}{l}28 \\
20 \\
10 \\
18 \\
76\end{array}$ & $\begin{array}{r}12 \\
7 \\
3 \\
6 \\
28\end{array}$ & $\begin{array}{l}\left.\begin{array}{l}341 \\
209 \\
107 \\
187 \\
844\end{array}\right\}\end{array}$ & $\begin{array}{l}65 \\
13 \\
22\end{array}$ \\
\hline \multicolumn{7}{|c|}{ Royal Free Hospital (H.D.J. and R.M.) } \\
\hline $\begin{array}{l}\text { Type I } \\
\text { Category Ia } \\
\text { Type II } \\
\text { Type III } \\
\text { Totals }\end{array}$ & $\begin{array}{r}67 \\
27 \\
73 \\
74 \\
241\end{array}$ & $\begin{array}{r}71 \\
18 \\
35 \\
34 \\
158\end{array}$ & $\begin{array}{r}7 \\
5 \\
6 \\
6 \\
24\end{array}$ & $\begin{array}{l}4 \\
0 \\
3 \\
2 \\
9\end{array}$ & $\left.\begin{array}{r}149 \\
50 \\
117 \\
116 \\
432\end{array}\right\}$ & $\begin{array}{l}46 \\
27 \\
27\end{array}$ \\
\hline
\end{tabular}

Royal Free and Hammersmith Hospitals (other surgeons)

Type

Category Ia

Type II

Type IJI

$\left.\begin{array}{rrrrrl}51 & & 35 & 17 & 1 & 104 \\ 97 & . . & 74 & 11 & 4 & 186 \\ 85 & & 60 & 7 & 6 & 158 \\ 62 & & 32 & 5 & 1 & 100 \\ 295 & & 201 & 40 & 12 & 548\end{array}\right\}$

Middlesbrough Hospital

Type I

Type III

Totals

101
83

83
61
245

99
29
30

$$
\begin{array}{r}
14 \\
15 \\
4 \\
33
\end{array}
$$

$\begin{array}{rr}3 & 217 \\ 2 & 129 \\ 1 & 96 \\ 6 & 442\end{array}$

Bristol

Type I

Type II

Type III

Totals

$\begin{array}{rr}95 & 82 \\ 39 & 25 \\ 35 & 30 \\ 169 & 137\end{array}$

$\begin{array}{rrr}5 & 7 & 189 \\ 4 & 3 & 71 \\ 6 & 2 & 73 \\ 15 & 12 & 333\end{array}$

Belfast

Type I

Category Ia

Type II

Type III

Totals

$\begin{array}{rr}49 & 57 \\ 33 & 28 \\ 41 & 15 \\ 75 & 18 \\ 198 & 1\end{array}$

$\left.\begin{array}{rrrr}57 & 7 & 3 & 116 \\ 28 & 7 & 2 & 70 \\ 15 & 3 & 0 & 59 \\ 18 & 7 & 2 & 102 \\ 118 & 24 & 7 & 347\end{array}\right\}$

Preston

Type I

Type II

Type III

Totals

$\begin{array}{rr}37 & 52 \\ 42 & 12 \\ 26 & 13 \\ 105 & 77\end{array}$

$\begin{array}{rrrr}52 & 7 & 5 & 101 \\ 12 & 4 & 0 & 58 \\ 13 & 5 & 0 & 44 \\ 77 & 16 & 5 & 203\end{array}$

${ }^{1}$ The final column gives the proportion of patients with ulcers of each type at each centre.

TABLE II

TOTAL NUMBERS OF PATIENTS IN WHOLE SERIES WITH EACH TYPE OF ULCER AND EACH ABO BLOOD GROUP

\begin{tabular}{|c|c|c|c|c|c|c|}
\hline & $O$ & $A$ & $B$ & $A B$ & Totals & Proportions \\
\hline $\begin{array}{l}\text { Type I } \\
\text { (strict) }\end{array}$ & 777 & 749 & 128 & 49 & 1,703 & $57 \%$ \\
\hline Category Ia & 349 & 287 & 54 & 17 & 707 & \\
\hline Type II & 507 & 299 & 61 & 22 & 889 & $21 \%$ \\
\hline Type III & 521 & 298 & 68 & 15 & 902 & $21 \%$ \\
\hline Totals & 2,154 & 1,633 & 311 & 103 & 4,201 & \\
\hline
\end{tabular}

TABLE III

BLOOD GROUP PROPORTIONS FOR THREE TYPES OF ULCER AND FOR WHOLE SERIES ${ }^{1}$

18

(18)

60

10

30

65

22

Cot

$$
\text { Cont }
$$

$$
\text { of }
$$

${ }^{1}$ The controls have been weighted in simple proportion to the number
of patients in each category from each centre. The relative incidence of type I ulcers, A to non-A, was 1-16.

\section{TYPE II ULCERS}

(1)
The apparent incidence of ulcers of type II in persons of group $\mathrm{O}$ relative to their incidence in persons of other groups was 1.50 (Table VI.) This compares with the overall figures of 1.19 for the whole series, and the world-wide figures for gastric ulcers of all types of 1.19 and 1.38 for duodenal ulcers. All but one of the 10 areas showed an excess of group $O$ and in four it was individually of very significant size. The overall relative incidence gave $\chi^{2}$ as 33.5 for 1 degree of freedom ( $P=1$ in several thousand) but there was considerable heterogeneity in the size of the margin from place to place $\left(\chi^{2}=27.0\right.$ for 9 degrees of freedom; $\mathbf{P}<0.01$ ).

\section{TYPE III ULCERS}

The apparent incidence of type III ulcers in persons of blood group $\mathrm{O}$ relative to their incidence in persons of other groups came to 1.58 (Table VII). $\chi^{2}$ for the difference from unity was $37 \cdot 1$ for 1 degree of freedom, which indicates a probability of fortuity of much less than one in a thousand. However, again $\chi^{2}$ for heterogeneity reached the high figure of 36.4 
TABLE V

ANALYSIS OF INCIDENCE OF TYPE I (STRICT) ULCERS IN PERSONS OF BLOOD GROUPS O AND A RELATIVE TO INCIDENCE IN PERSONS OF BLOOD GROUPS A AND NON-A RESPECTIVELY

Centre

No. of Cases in Series

Relative Incidence

$x^{2}$

Relative $O: A$ $A: O+B+A B$

St. James's, Balham

St. Bartholomews

University College

Central Middlesex

Royal Free (H.D.J. and R.M.)

Royal Free and Hammersmith (other surgeons)

Middlesbrough

Bristol

Preston

Belfast

Total

Mean weighted relative incidence

$x^{2}$ Total

Difference from unity $D$ of $F=1$

Heterogeneity: $D$ of $F=9$

P Heterogeneity

$\begin{array}{rrrrr}262 & 0.79 & 3.19 & 1.30 & 4.36 \\ 175 & 0.62 & 8 \cdot 16 & 1.38 & 4.60 \\ 49 & 1.27 & 0.64 & 0.93 & 0.06 \\ 341 & 1.20 & 2.30 & 0.86 & 1.81 \\ 149 & 0.81 & 1.47 & 1.33 & 3.06 \\ 104 & 1.25 & 1.06 & 0.74 & 2.03 \\ 217 & 0.88 & 0.76 & 1.26 & 2.68 \\ 189 & 1.20 & 1.42 & 0.93 & 0.24 \\ 101 & 0.65 & 3.82 & 1.49 & 3.83 \\ 116 & 0.65 & 4.75 & 1.64 & 7.09 \\ 1,703 & & & & 1.14 \\ & 0.91 & 23.57 & & 29.56 \\ & & 3.47 & & 7.20 \\ & & 24.15 & & 22.58 \\ & & <0.01 & & <0.01\end{array}$

TABLE VI

ANALYSIS OF INCIDENCE OF TYPE II GASTRIC ULCER IN PERSONS OF BLOOD GROUP O RELATIVE TO ITS INCIDENCE IN PERSONS OF OTHER GROUPS

\begin{tabular}{|c|c|c|c|c|c|}
\hline Centre & $\begin{array}{l}\text { No. of Cases } \\
\text { in Series }\end{array}$ & $\begin{array}{l}\text { Relative } \\
\text { Incidence } \\
O: A\end{array}$ & $x^{2}$ & $\begin{array}{l}\text { Relative } \\
\text { Incidence } \\
O: A+B+A B\end{array}$ & $x^{2}$ \\
\hline St. James's, Balham & 93 & 0.73 & 2.08 & 0.78 & 1.44 \\
\hline St. Bartholomews & 84 & 1.26 & 1.04 & 1.43 & 2.60 \\
\hline University College & 13 & $*$ & $*$ & $*$ & $*$ \\
\hline Central Middlesex & 107 & 1.07 & 0.09 & 1.06 & 0.09 \\
\hline Royal Free (H.D.J. and R.M.) & 117 & $1 \cdot 80$ & 8.06 & 1.86 & 10.57 \\
\hline Royal Free and Hammersmith (other surgeons) & 158 & $1 \cdot 22$ & $1 \cdot 38$ & $1 \cdot 31$ & $2 \cdot 80$ \\
\hline Middlesbrough & 129 & 2.46 & 16.44 & 2.09 & 15.06 \\
\hline Bristol & 71 & 1.62 & 3.47 & 1.58 & 3.60 \\
\hline Preston & 58 & $3 \cdot 20$ & $12 \cdot 35$ & $3 \cdot 14$ & 14.85 \\
\hline Belfast & 59 & 2.07 & 5.83 & $2 \cdot 39$ & $9 \cdot 50$ \\
\hline Total & 889 & & & & \\
\hline Mean weighted relative incidence & & 1.44 & & $1 \cdot 50$ & \\
\hline $\begin{array}{l}x^{2} \text { Total } \\
\text { Difference from unity } D \text { of } F=1 \\
\text { Heterogeneity: } D \text { of } F=9\end{array}$ & & & $\begin{array}{l}50 \cdot 74 \\
23.76 \\
27 \cdot 00\end{array}$ & & $\begin{array}{r}60 \cdot 51 \\
33 \cdot 52 \\
27 \cdot 00\end{array}$ \\
\hline
\end{tabular}

*Numbers too small.

TABLE VII

ANALYSIS OF INCIDENCE OF TYPE III GASTRIC ULCERS IN PERSONS OF BLOOD GROUP O RELATIVE TO ITS INCIDENCE IN PERSONS OF OTHER GROUPS

Centre

$\begin{array}{llll}\begin{array}{l}\text { No. of Cases } \\ \text { in Series }\end{array} & \begin{array}{l}\text { Relative } \\ \text { Incidence } \\ O: A\end{array} & x^{2} & \begin{array}{l}\text { Relative } \\ \text { Incidence } \\ O: A+B+A B\end{array} \\ & & \end{array}$

St. James's, Balham

St. Bartholomews

University College

Central Middlesex

Royal Free (H.D.J. and R.M.)

Royal Free and Hammersmith (other surgeons)

Middlesbrough

Bristol

Preston

Belfast

Total

Mean weighted relative incidence

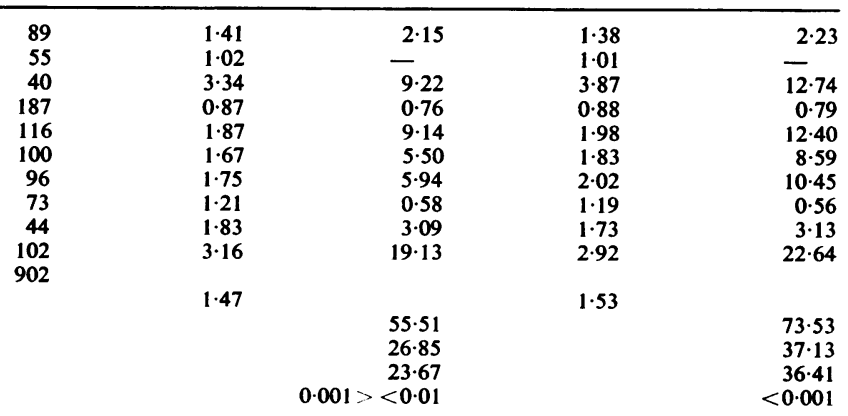

$x^{2}$ Total

Difference from unity $D$ of $F=1$

Heterogeneity: $D$ of $F=9$

P Heterogeneity 
TABLE VIII

COMPARISON OF INCIDENCES OF ULCERS OF TYPES II OR III AND TYPE I IN PERSONS OF BLOOD GROUP O RELATIVE TO THEIR INCIDENCES IN PERSONS OF OTHER GROUPS

\begin{tabular}{|c|c|c|c|c|c|c|}
\hline Centre & $\begin{array}{l}\text { No. of Cases } \\
\text { of Type I }\end{array}$ & $\begin{array}{l}\text { No. of Cases } \\
\text { of Types II } \\
\text { and III }\end{array}$ & $\begin{array}{l}\text { Relative } \\
\text { Incidence II } \\
\text { or III to I } \\
O: A\end{array}$ & $\chi^{2}$ & $\begin{array}{l}\text { Relative } \\
\text { Incidence II } \\
\text { or III to I } \\
O: A+B+A B\end{array}$ & $\chi^{2}$ \\
\hline St. James's, Balham & 262 & 182 & $1 \cdot 26$ & $1 \cdot 30$ & $1 \cdot 21$ & 0.95 \\
\hline St. Bartholomews & 175 & 139 & 1.88 & $6 \cdot 64$ & $2 \cdot 07$ & $9 \cdot 76$ \\
\hline University College & 49 & 53 & $2 \cdot 15$ & 2.95 & 1.90 & $2 \cdot 34$ \\
\hline Central Middlesex & 341 & 294 & $0 \cdot 78$ & 2.02 & 0.79 & $2 \cdot 08$ \\
\hline Royal Free (H.D.J. and R.M.) & 149 & 233 & $2 \cdot 26$ & $13 \cdot 18$ & $2 \cdot 09$ & 11.96 \\
\hline Royal Free and Hammersmith (other surgeons) & 104 & 258 & $1 \cdot 10$ & $0 \cdot 13$ & $1 \cdot 38$ & 1.88 \\
\hline Middlesbrough & 217 & 225 & $2 \cdot 39$ & $17 \cdot 33$ & $2 \cdot 04$ & $13 \cdot 48$ \\
\hline Bristol & 189 & 144 & $1 \cdot 16$ & 0.41 & 1.05 & 0.04 \\
\hline Preston & 101 & 102 & 3.82 & $17 \cdot 81$ & 3.46 & $17 \cdot 75$ \\
\hline Belfast & 116 & 161 & $4 \cdot 09$ & $25 \cdot 80$ & 3.52 & $23 \cdot 98$ \\
\hline Total & 1,703 & 1,791 & & & & \\
\hline Mean weighted relative incidence I to II + III & & & $1 \cdot 59$ & & 1.54 & \\
\hline $\begin{array}{l}x^{2} \text { Total } \\
\text { Difference from unity } D \text { of } F=1 \\
\text { Heterogeneity } D \text { of } F=9 \\
\text { P Heterogeneity }\end{array}$ & & & & $\begin{array}{l}87 \cdot 58 \\
38.92 \\
48 \cdot 66 \\
0 \cdot 001\end{array}$ & & $\begin{array}{l}84 \cdot 22 \\
38 \cdot 21 \\
46 \cdot 00 \\
0 \cdot 001\end{array}$ \\
\hline
\end{tabular}

for 9 degrees of freedom, which indicates considerable variation from place to place, which had virtually no chance of being fortuitous.

\section{COMPARISON OF TYPE I WITH TYPES II AND III}

Some of the marked variation which occurred from place to place might have been due to varying degrees of representativeness of the controls. In order to eliminate errors introduced from this source we therefore compared the relative incidence of type $\mathbf{I}$ ulcers with that of ulcers of types II and III. Again the difference gave the very high $\chi^{2}$ value of 38.2 for 1 degree of freedom $(P<0.001)$ but again there was marked heterogeneity between the areas $\left(\chi^{2}=46.0\right.$ for 9 degrees of freedom; $\mathrm{P}<0.001$ ).

\section{DIFFERENCES IN ACID-SECRETION PATTERN}

It has already been shown on the basis of a relatively small number of cases that subjects with type I ulcers secrete less resting juice and juice of lower acidity, on the average, than normal subjects. Patients with ulcers of types II or III, on the other hand, usually show well-marked hypersecretion (Johnson, 1957b). Larger numbers are now available and the volumes and acidities of spontaneous nocturnal secretion of 153 gastric ulcer subjects have been compared statistically. Half the patients secreted less and half more than $102 \mathrm{ml}$. of juice. Of the type I ulcer subjects, 49 secreted less and 21 more than this amount. Of the subjects with ulcers of types II or III, 27 secreted less and 55 more (Table IX). When these figures are compared by the standard method they give $\chi^{2}$ as 20.8 for 1 degree of freedom. The bulked juice of half the gastric ulcer subjects had an acidity of less than $15 \mathrm{mEq}$./l. The whole-night juice of 45 of the type I ulcer subjects was less acid than this and of 18 it was more acid. Of the type II and III ulcer subjects, 31 failed to reach the mean level and 58 exceeded it (Table X). This time statistical comparison gives a $\chi^{2}$ of 30.6 for 1 degree of freedom. There is therefore only a chance of one in many thousands of fortuity and very strong evidence that subjects with ulcers of type I, on the one hand, and

TABLE IX

TITRATABLE ACIDITY OF BULKED ALL-NIGHT GASTRIC SECRETION IN 153 GASTRIC ULCER SUBJECTS ${ }^{1}$ Acidity (mEq./l.)

Type of ulcer $0-10-20-30-40-50-60-70-80-90-$

\begin{tabular}{lrrrrrrrrrr}
\hline I & 39 & 9 & 7 & 3 & 1 & 2 & 1 & 1 & 1 & 0 \\
II or III & 17 & 16 & 9 & 9 & 10 & 15 & 6 & 4 & 1 & 2
\end{tabular}

Total

$\begin{array}{llllllllll}56 & 25 & 16 & 12 & 11 & 17 & 7 & 5 & 2 & 2\end{array}$

${ }^{1}$ Most of those ulcers of type II with very low acidities had evidence of gastric retention.

TABLE X

VOLUME OF ALL-NIGHT GASTRIC SECRETION IN 153 GASTRIC ULCER SUBJECTS Volume of Secretion (ml.)

\begin{tabular}{|c|c|c|c|c|c|c|c|c|c|c|c|}
\hline Type of Ulcer & 0 & 100 & 200 & 300 & 400 & 500 & 600 & 700 & 800 & 900 & $1,000+$ \\
\hline $\begin{array}{l}\text { I } \\
\text { II or III } \\
\text { Total }\end{array}$ & $\begin{array}{r}23 \\
5 \\
28\end{array}$ & $\begin{array}{l}24 \\
21 \\
45\end{array}$ & $\begin{array}{l}13 \\
11 \\
24\end{array}$ & $\begin{array}{r}4 \\
12 \\
16\end{array}$ & $\begin{array}{l}0 \\
7 \\
7\end{array}$ & $\begin{array}{r}2 \\
8 \\
10\end{array}$ & $\begin{array}{l}2 \\
3 \\
5\end{array}$ & $\begin{array}{l}1 \\
5 \\
6\end{array}$ & $\begin{array}{l}0 \\
5 \\
5\end{array}$ & 1 & $\begin{array}{l}0 \\
5 \\
5\end{array}$ \\
\hline
\end{tabular}


those with types II and III, on the other, have very different resting acid secretion patterns. Again the lesions characterized by hypersecretion are associated with blood group $\mathrm{O}$ excess and those with hyposecretion with excess of group A.

\section{DISCUSSION}

Both the blood group studies and the acid secretion investigations have clearly shown that gastric ulcers are of two quite different kinds. Prepyloric ulcers and gastric ulcers which are combined with, and probably secondary to, duodenal ulcers, both tend to be found in subjects who are hypersecreting and also predominantly of blood group $O$. In fact there is good evidence that the excess is even greater in these patients than among those with duodenal ulcers alone. On the other hand patients with ulcers well away from the pylorus and without preceding duodenal or juxta-pyloric lesions are characterized by a tendency towards hyposecretion of acid and have no evidence of any association with blood group $\mathrm{O}$. Indeed there is a significant excess in them of group A.

Evidence for a general relationship between blood group $\mathbf{O}$ and hypersecretion was put forward by Køster, Sindrup, and Seele (1955) who pointed out that subjects with diseases such as pernicious anaemia and carcinoma of the stomach, which carry a tendency to preponderance of group A, are also characterized by hyposecretion, and those subjects suffering from conditions with excess of $\mathrm{O}$, such as duodenal ulcers, also have hypersecretion of hydrochloric acid. They showed that the relationship had a high level of statistical significance. For peptic ulcer subjects further support came from the figures of Buckwalter, Wohlwend, Colter, Tidrick, and Knowler (1956), of Brown et al. (1956), and from our own data.

Brown and his co-workers have been cited as having established that there is no relation between hypersecretion and the $\mathrm{ABO}$ blood groups, and this is indeed what they stated in their summary. But in the body of their paper they reported that the mean maximal acid output of 160 group $O$ ulcer patients was higher than that of $\mathbf{8 8}$ of group A; in the case of the 39 with gastric ulcers it was about $30 \%$ higher. Their evidence did in fact point in the same direction as our own and that of others, though it did not by itself in this small series attain statistical significance.

However, among peptic ulcer subjects the case was strongest for those with gastric ulcers, and in them might have been no more than an expression of the fact brought out in this study that gastric ulcers of different kinds occur, one kind in hyposecretors and the other in hypersecretors of acid, only the latter being associated, possibly for some other reason, with group $\mathrm{O}$ excess. We therefore compared resting secretion levels of 'Os' with 'As' among 156 duodenal ulcer patients. There was indeed a small excess of group $O$ subjects both among those who secreted a larger than average volume of resting juice (Table XII), and among those whose juice was more acid than the average for all duodenal ulcer patients (Table XI). Among those who were below average in either respect there was an excess of As. However,

TABLE XI

TITRATABLE 'FREE' ACIDITY OF BULKED SPONTANEOUS WHOLE-NIGHT GASTRIC SECRETION IN 156 DUODENAL ULCER SUBJECTS ${ }^{1}$

\begin{tabular}{|c|c|c|c|c|c|c|c|c|c|c|c|c|}
\hline \multirow[b]{2}{*}{ Blood Group } & \multicolumn{12}{|c|}{ Free Acid (mEq./l.) } \\
\hline & 0 & 10 & $20-$ & $30-$ & $40-$ & $50-$ & $60-$ & 70 & 80 & 90 & 100 & $110+$ \\
\hline O & 12 & 8 & 13 & 13 & 12 & 15 & 10 & 10 & 10 & 4 & 3 & 2 \\
\hline $\mathbf{A}$ & 14 & 1 & 5 & 10 & 6 & 5 & 7 & 3 & 2 & - & - & - \\
\hline B & 1 & - & 2 & - & - & 4 & 2 & - & - & - & - & - \\
\hline AB & - & - & - & - & 2 & - & 1 & - & - & - & - & - \\
\hline Totals & 27 & 9 & 20 & 25 & 19 & 24 & 20 & 13 & 12 & 4 & 3 & 2 \\
\hline
\end{tabular}

Most of those with very low levels of acidity had evidence of pyloric obstruction and intragastric buffering.

TABLE XII

VOLUME OF WHOLE-NIGHT GASTRIC SECRETION ASPIRATED FROM 156 DUODENAL ULCER SUBJECTS BY BLOOD GROUPS

Gastric Secretion ( $m l$.

\begin{tabular}{|c|c|c|c|c|c|c|c|c|c|c|c|c|c|c|}
\hline Blood Group & 0 & 100 & $200-$ & $300-$ & 400 & $500-$ & $600-$ & $700-$ & 800 & 900 & 1,000 & 1,100 & 1,200 & 1,300 \\
\hline O & 8 & 22 & 14 & 10 & 13 & 16 & 4 & 3 & 8 & 2 & 1 & 5 & - & 1 \\
\hline $\mathbf{A}$ & 4 & 13 & 8 & 4 & 2 & 10 & - & 3 & 3 & 1 & - & - & 1 & - \\
\hline B & 1 & - & 2 & - & 2 & - & 1 & - & 1 & 1 & 1 & - & - & - \\
\hline $\mathbf{A B}$ & 2 & - & - & 1 & - & - & 1 & - & - & - & - & 1 & - & - \\
\hline Totals & 15 & 35 & 24 & 15 & 17 & 26 & 6 & 6 & 12 & 4 & 2 & 6 & 1 & 1 \\
\hline
\end{tabular}


like the margin in blood group distribution itself, it was much too small, even if real, to achieve statistical significance in a small series. Only the consistency of the same findings among so many workers suggests that this apparent association may ultimately prove to be a real one.

The level of serum pepsinogen is believed to be a reasonable index of the acid-secreting cell mass in the stomach, and Hanley (1964) found in 800 normal subjects that both the group $\mathrm{O}$ and non-secretor phenotypes had higher mean serum pepsinogen levels. The difference between the group $O$ nonsecretors and group A secretors was significant at a level of $1 \%$.

Evidence has also been reported that the more severe the ulcers the greater the preponderance of group $O$ among the patients (Brown et al., 1956). Recurrent ulcers carry a particularly high proportion (Doll and Swynnerton, 1960), and the tendency for recurrences to occur mainly among gross oversecretors of acid was commented on many years ago (Wright, 1935; Orr and Johnson, 1947).

Baron (1963) has demonstrated a gradient of acid secretion, ulcers in the body of the stomach being associated with the lowest and ulcers near the pylorus with the highest, levels. This is similar to the gradient which we have found for blood group $\mathrm{O}$ preponderance. It may well be that diseases which are associated with group $\mathbf{O}$ are so associated only because they are found in persons predisposed by a tendency to hypersecretion of hydrochloric acid and that this is partly hereditary.

Card and Marks (1960), and, by a different technique Capper, Laidlaw, Buckler, and Richards (1962), have shown that acid hypersecretion is characterized by a larger than average area of acidsecreting mucosa or oxyntic-cell population, and it is presumably this anatomical feature which is hereditary.

The suggestion has been made that rather than blood group $\mathrm{O}$ being associated with an ulcerogenic factor, group A may carry a protective one, or even that blood group A substance is itself protective. Clarke et al. (1956) observed that duodenal ulcers were less common in those who secreted blood group substances in their digestive juices than in those who did not, and they suggested that the $\mathrm{H}$ substance secreted by group $O$ secretors gave some protection but less than that given by the A substance. However, our finding that type I gastric ulcers are more apt to occur in group $\mathrm{A}$ than in group $\mathrm{O}$ subjects appears to refute this hypothesis. The apparent fact that different kinds of ulcers occur predominantly in subjects of different blood groups does not allow of the possibility of either group being associated with a single hereditary protective factor, nor indeed with a single hereditary ulcerogenic factor responsible for all kinds of ulcer either.

Wolf and Wolff (1943) observed that acid secretion and the production of mucin seemed to go hand in hand (though there is evidence that no close relationship exists). It is certainly not usual for a hypersecretor of acid to develop an ulcer in the body of the stomach unless he first has a duodenal or pyloric lesion and some interference with gastric emptying. This could be because excess of acid in a hypersecretor promotes an adequate flow of mucus for defence of the stomach, though not of the duodenum. However, a hyposecretor of acid may have inadequate stimulation to mucus secretion and on that account be vulnerable even to his diminished acid/peptic attack. It was suggested, therefore, that type I gastric ulcer is a disease of hyposecretion (Johnson, 1957a).

Though the blood group relationships described are all well marked, the series shows striking lack of homogeneity between the contributing areas, both in respect of the group A excess in type I ulcer patients and also for the group $\mathrm{O}$ excess in patients with ulcers of types II or III. The size of the excess has varied by a wide margin from glace to place, and evidently this cannot be attributed to chance. Some of this heterogeneity is probably due to variations in representativeness of controls, for it is particularly noticeable between different parts of London. All the London series were compared with the same controls, though considerable differences are known to exist between areas with, for example, greater or lesser proportions of Irish in the local population (Table XIII). Some areas show quite atypical overall pictures, with the relative incidences for the various types of ulcer consequently all shifted in the same direction.

However, this would not account for the hetero-

\section{TABLE XIII}

COMPARISON OF BLOOD GROUP DISTRIBUTIONS FOR WEST LONDON FROM VARIOUS SOURCES

\begin{tabular}{lllrlr} 
& \multicolumn{6}{l}{ Blood Group (\%) } \\
\cline { 2 - 6 } Series & \multicolumn{1}{l}{$\boldsymbol{O}$} & \multicolumn{1}{c}{$\boldsymbol{B}$} & \multicolumn{1}{c}{$A B$} & \multicolumn{1}{c}{ Total } \\
\hline Discombe and Meyer & $45 \cdot 78$ & $42 \cdot 19$ & $8 \cdot 90$ & $3 \cdot 13$ & 10,000 \\
Pearson and Pinker & $46 \cdot 04$ & $40 \cdot 12$ & $10 \cdot 26$ & $3 \cdot 56$ & 11,086 \\
Kopec & $47 \cdot 11$ & $40 \cdot 56$ & $9 \cdot 23$ & $3 \cdot 10$ & 19,473 \\
Royal Free Hospital & $45 \cdot 38$ & $39 \cdot 33$ & $12 \cdot 10$ & $3 \cdot 19$ & $3 \cdot 883$
\end{tabular}

1Discombe and Meyer (1952) 10,000 ante-natal patients from Park Royal Hospital, London, N.W.10.

Pearson and Pinker (1956) 11,086 ante-natal patients from Hammersmith Hospital, London, W.12.

Kopec (1963) Blood donors from western London.

Royal Free Hospital. Patients attending Royal Free Hospital, London, W.C.1, ante-natal department, November 1960 to November 1963. These figures would have been quite different if the $15 \%$ of Irish with high $O$ had not happened to be balanced by $11 \%$ of Greek Cypriots with high A. 
geneity observed in the internal comparison shown in Table VIII. This could be due to differences of precision with which the ulcer types have been separated in different hands.

If type I gastric ulcer is indeed a disease of hyposecretion as postulated, its apparent association with blood group A might have been guessed to be an expression of its tendency not to occur in hypersecreting group $\mathbf{O}$ subjects. However, this should also have led to an increased incidence in subjects of groups $B$ and $A B$ which is the reverse from what we have observed. For what our small figures are worth they are nearly all consistently against this hypothesis.

Pyloric obstruction has been seen commonly to promote a gastric ulcer proximal to it, usually to the left of the gastric angulus and in a position similar to that characteristic of ulcers of type I. Since the operation of vagotomy (alone) resulted in gastric retention one of us hazarded a guess that it too might lead to a gastric ulcer (Johnson, 1948). Before long this was indeed one of the reasons why vagotomy alone was abandoned. We have seen cases of benign gastric ulcer proximal to obstructing antral carcinomas, and others were mentioned by Aird, Bentall, and Roberts (1953). However, duodenal and prepyloric ulcers are by far the commonest causes of gastric retention and it was to be expected that the majority of cases of ulcer associated with gastric retention should also have hypersecretion and a group $\mathrm{O}$ preponderance. But, the occasional discovery of one complicating a prepyloric carcinoma with hypochlorhydria suggests that retention rather than acid hypersecretion may be the more important factor in pathogenesis in ulcers of type II. Overwhelming of mucus secretion by an excessively powerful acid-peptic attack may be all-important in these cases.

It is a pleasure to express our indebtedness to those who have kindly allowed us to use their case notes, to their records officers and to Kamal Bushra, F.R.C.S., who have given us much help, to Mr. Capper, Dr. Doll, Mr. Grahame, Mr. Maingot, Mr. Orr, Professor Pilcher, Mr. Tanner, Professor Taylor, Professor Welbourn, and to the late Professor Ian Aird.

Our particular thanks are due to Dr. J. A. Fraser Roberts who has given us valuable advice.

We are also indebted to the Trustees of the Peter Samuel Trust for medical research who have generously met our expenses, and to the Hon. Peter Samuel himself who established the Trust.

\section{SUMMARY}

The purpose of this paper was to establish that gastric ulcers, which have themselves but recently won recognition as a disease entity separate from duodenal ulcers, should more properly be further subdivided. This was done by showing that when gastric ulcers were put into categories in accordance with certain simple criteria, not only were the acidsecretion patterns associated with the categories convincingly dissimilar, but also their blood group characteristics differed to a statistically highly significant degree.

Gastric ulcers have been shown to be of two main kinds, one associated with hypersecretion and a very marked blood group $\mathrm{O}$ predominance, and the other with hyposecretion, having no evidence whatever of group $\mathrm{O}$ preponderance, but in fact strong evidence for an excess of group A. Hypersecretion ulcers fall into two types found in different situations. One is an ulcer occurring in the body of the stomach secondary to a duodenal ulcer; the other is prepyloric and is already well recognized to have more in common with duodenal ulcers than with other ulcers elsewhere in the stomach.

Hypersecretion ulcers make up about half of all surgically treated gastric ulcers. Together they have been the source of the whole of the overall group $\mathrm{O}$ excess in this series. They are $50 \%$ more likely to occur in persons of blood group $\mathrm{O}$ than in those of other groups. Since most series of gastric ulcers contain a mixture of types with opposite blood group characteristics, it is not surprising that the overall features reported from different centres have been so varied and contradictory.

\section{REFERENCES}

Aird, I., Bentall, H. H., Mehigan, J. A., and Roberts, J. A. F. (1954). The blood groups in relation to peptic ulceration and carcinoma of colon, rectum, breast, and bronchus. Brit. med. J., 11, 315-321.

,-- , and Roberts, J. A. F. (1953). A relationship between cancer of stomach and the ABO blood groups. Ibid., 1, 799-801.

Balme, R. H., and Jennings, D. (1957). Gastric ulcer and the ABO blood-groups. Lancet, 1, 1219-1220.

Baron, J. H. (1963). An assessment of the augmented histamine test in the diagnosis of peptic ulcer. Gut, 4, 243-253.

Billington, B. P. (1956). ABO blood groups and gastroduodenal diseases. Aust. Ann. Med., 5, 141-148.

- (1958). Combined gastric and duodenal ulcer. Lancet, 2, 753.

Brown, D. A. P., Melrose, A. G., and Wallace, J. (1956). The blood groups in peptic ulceration. Brit. med. J., 2, 135-138.

Buckwalter, J. A., Wohlwend, E. B., Colter, D. C., Tidrick, R. T., and Knowler, L. A. (1956). Peptic ulceration and ABO blood groups. J. Amer. med. Ass., 162, 1215-1220.

Burge, H., Gill, A. M., and Lewis, R. H. (1963). The pyloric-channel syndrome and gastric ulceration. Lancet, 1, 73-75.

Capper, W. M., Laidlaw, C. D'A., Buckler, K., and Richards, D. (1962). The $p H$ fields of the gastric mucosa. Lancet, 2,12 00-1202.

Card, W. I., and Marks, I. N. (1960). The relationship between the. acid output of the stomach following 'maximal' histamine stimulation and the parietal cell mass. Clin. Sci., 19, 147-163.

Clarke, C. A., Cowan, W. K., Edwards, J. W., Howel-Evans, A. W., McConnell, R. B., Woodrow, J. C., and Sheppard, P. M. (1955). The relationship of the ABO blood groups to duodenal and gastric ulceration. Brit. med. J., 2, 643-646.

—, Edwards, J. W., Haddock, D. R. W., Howel-Evans, A. W., McConnell, R. B., and Sheppard, P. M. (1956). ABO blood groups and secretor character in duodenal ulcer. Ibid., 2 , 725-731. 
Discombe, G., and Meyer, H. (1952). The capillary-tube method of rhesus testing, with a report on blood group frequencies in North West London. Amer. J. clin. Path., 22, 543-548.

Doll, R., Swynnerton, B. F., and Newell, A. C. (1960). Observations on blood group distribution in peptic ulcer and gastric cancer. Gut, 1, 31-35.

Grahame, E. W. (1961). The ABO blood groups and peptic ulceration. Brit. med. J., 1, 95-96.

Hanley, W. B. (1964). Thesis for M.D. Liverpool.

Johnson, H. D., (1948). Vagotomy-the present position. Postgrad. med. J., 24, 193-198.

- (1955a). The special significance of concomitant gastric and duodenal ulcers. Lancet, 1, 266-270.

- (1955b). Correspondence with Aird, I., referred to by Aird, Brit. med. J., 1, 919.

(1957a). The pathogenesis of peptic ulcers. Lancet, 2, 515-517. (1957b). The classification and principles of treatment of gastric ulcers. Ibid., 2, 518-520.

Kopec, A. C. (1963). Personal communications.

Køster, K. H., Sindrup, E., and Seele, V. (1955). ABO blood-groups and gastric acidity. Lancet, 2, 52-55.

Orr, I. M., and Johnson, H. D. (1947). Vagal resection in the treatment of duodenal ulcer. Ibid., 2, 84-88.

Pearson, M. G., and Pinker, G. D. (1956). ABO blood groups and toxaemia of pregnancy. Brit. med. J., 1, 777-778.

Roberts, J. A. Fraser (1957). Blood groups and susceptibility to disease: a review. Brit. J. prev. soc. Med., 11, 107-125.

Wolf, S., and Wolff, H. G. (1943). Human Gastric Function, p. 69. Oxford University Press, London.

Woolf, B. (1955). On estimating the relation between blood group and disease. Ann. hum. Genet., 19, 251-253.

Wright, G. (1935). Collective inquiry by the Fellows of the Association of Surgeons into gastrojejunal ulceration. Brit. J. Surg., 22, 433-455. 
Brien, F. S., Turner, D. A., Watson, E. M., and Geddes, J. H. (1952). A study of carbohydrate and fat absorption from the norma and diseased intestine in man. II. Changes from the serum lipids in man after the ingestion of butterfat with and without Tween 80 (Sorlate). Ibid., 20, 294-297.

Bučko, A., and Dvorský, A. (1957). Zur Frage der Stoffwechselstörungen nach Cholezystektomie. Dtsch. $Z$. Verdau-V. Stoffwechselkr., 17, 179-186.

Cottet, J. (1939). Les sels biliaires en bilogie et en thérapeutique. J. belg. Gastro-ent., 7, 165-190.

Dawson, A. M., and Isselbacher, K. J. (1960). Studies on lipid metabolism in the small intestine with observation on the role of bile salts. J. clin. Invest., 39, 730-740.

Demole, M., and Arpin-Morand, M. (1952). L'utilisation de la réaction au bleu de Nil comme moyen d'appréciation rapide de la teneur en graisses des matières fécales. Gastroenterologia (Basel), 78, 249-254.

Fedor, E. J., and Fisher, B. (1960). The use of radioactive iodine labeled triolein in the evaluation of fat absorption following cholecystectomy. Surg. Gynec. Obstet., 111, 206-210.

Ginter, E., Bobek, P., Blažek, Z., and Cerveň, J. (1963). The effect of experimental cholecystectomy on the resorption of $I^{131}$-labelled fats in cats. Gastroenterologia (Basel), 99, 301-310.

Heersma, J. R., and Annegers, J. H. (1948). Effect of cholecystectomy on fecal fat excretion in dogs. Proc. Soc. exp. Biol. (N.Y.). 69 , 140-141.

Holt, L. E. Jr., Tidwell, H. C., Kirk, C. M., Cross, D. M., and Neale, S. (1935). Studies in fat metabolism. I. Fat absorption in normal infants. J. Pediat., 6, 427-480.

Ivy, A. C. (1953). Physiology of the liver, bile and gall bladder. In Portis S. A.: Diseases of the Digestive System, 3rd ed., pp. 128-147. Lea and Febiger, Philadelphia.

Jones, C. M., Culver, P. J., Drummey, G. D., and Ryan, A. E. (1948). Modification of fat absorption in the digestive tract by the use of an emulsifying agent. Ann. intern. Med., 29, 1-10.

Kamer, van de J. H., Huinink, H. ten Bokkel, and Weyers, H. A. (1949). Rapid method for determination of fat in feces. $J$. biol Chem., 177, 347-355.

Krondl, A., and Bohdalová, V. (1959). Použiti syntetickych emulgátoru $v$ lexçà steatorrhey. (The use of synthetic emulgators in therapy of steatorrhoea.) Cs. Gastroent. Výž., 13, 36.
Krondl, Michalec, C., Vavřinková, H., and Vokáč, V. (1961a). Vyznam koncentrace žlučových kyselin pro přeměnu tukủ. I. Stěpeni a emulgace tuků u clověka. (The role of concentration of bile acids in fat metabolism. I. The digestion and emulgation of fat in man.) Ibid., 15, 31-38.

$\ldots$ - - - and Placer, Z. (1961b). Vyznam koncentrace žlucovych kyselin pro přemènu tuku . 2. Tráveni tuku s rủznym bodem tani. (The role of concentration of bile acids in fat metabolism. 2. Digestion of two lipids with different melting points.) Ibid., $15,112-116$

$-\ldots, \ldots$, and Michalec, C. (1961)c. Význam koncentrace žluxových kyselin pro přeměnu tuků. 3. Vstřebávání tuků u clověka. (The role of concentration of bile acids in fat metabolism. 3. The fat absorption in man.) Ibid., 15, 282-289.

_- , and Vavŕinková, H. (1961d). Význam koncentrace zllučových kyselin pro přemexnu tuků. 4. Vliv hovězi žlư̌e a Tweenu 80 na vstřebávání tuků u člověka. (The role of concentration of bile acids in fat metabolism. 4. The influence of ox bile and Tween 80 on the fat absorption in man.) Ibid., 15, 371-377.

- - (1961e). Význam koncentrace żlučových kyselin pro přemènu tuků. 5. Vylučování tuků u člověka. 6. Shrnuti a závěry ze sděleni $1-5$. (The role of concentration of bile acids in fat metabolism. 5. The elimination of fat in man. 6 . Summary and conclusions.) Ibid., 15, 378-381.

Minard, F. N. (1953). The inhibition of the action of pancreatic lipase by esters of polyoxyethylene sorbitan. J. biol. Chem., 200. 657-660.

Redetzki, H., and Gronow, R. T. (1955). Untersuchungen über die Fettresorption und die alimentare lipamie nach Fettbelastung. Klin. Wschr., 33, 701-705.

Schöndube, W. (1956). Die Erkrankungen der Gallenwege. Enke, Stuttgart.

Siegel, S. (1956). Nonparametric statistics: for the behavioural sciences. pp. 116-127. McGraw-Hill, New York.

Stern, I., and Shapiro, B. (1953). A rapid and simple method for the determination of esterified fatty acids and for total fatty acids in blood. J. clin. Path., 6, 158-160.

Tidwell, H. C., and Nagler, M. E. (1953). Effect of emulsifiers on fat absorption in the normal young adult. Gastroenteralogy, 23, 470-476.

CORRECTION

It is regretted that a phrase was omitted in the last sentence of the last paragraph in column 1 on page 410 of the paper 'Gastric ulcers, blood groups, and acid secretion' by $H$. Daintree Johnson, A. H. G. Love, N. C. Rogers, and A. P. Wyatt (Gut, 5, 402-411). The sentence should read: 'Overwhelming of mucus secretion by an excessively prolonzed rather than an excessively powerful acid-peptic attack may be all-important in these cases.' 